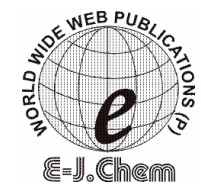

http://www.e-journals.net
ISSN: 0973-4945; CODEN ECJHAO

E-Journal of Chemistry

Vol. 5, No. 1, pp. 34-38, January 2008

\title{
Development and Evaluation of Herbal Formulations for Hair Growth
}

\author{
LIPI PURWAL, SURYA PRAKASH B.N GUPTA* and MILIND. S. PANDE ${ }^{*}$ \\ Purwal Clinic, 9 Dhanvantari, Old Thana Road Ashta, Sehore. (M.P.) \\ *Rajiv Gandhi Institute of Pharmacy, Satna (M.P.)-485001 \\ "Millennium College of Pharmacy, Bhopal (M.P.)-462021, India. \\ suryatony@yahoo.co.in
}

Received 13 January 2007; Accepted 2 March 2007

\begin{abstract}
Hair formulation of Emblica officinalis (Euphorbiaceae), Bacopa, monnieri (Scrophulariaceae), Trigonella foenumgraecum (Leguminosae), Murraya koenigii (Rutaceae) in various concentrations in the form of herbal oil were studied for their hair growth activity. Each drug was tested for their hair growth activity in a concentration range for $1-10 \%$ separately. Based on these results mixture of crude drugs Murraya koeniigi, leaf (Rutaceae), Bacopa monnieri, leaf (Scrophulariaceae), Trigonella foenumgraecum (Leguminosae), Murraya koenigii (Rutaceae) were prepared in varying concentration in the form of herbal hair oil by three different oils preparation techniques and were tested for hair growth activity. The result revealed that the hair growth activity of each drug was found proportional to the concentration range tested. Similarly higher concentrations of drug in the formulation were found to have higher hair growth activities. But looking towards the formulation viscosity the maximum concentration of combined drug was found to be $30 \%$ at their maximum level. The formulation containing $7.5 \%$ of each drug used for the study and showed excellent hair growth activity with standard (2\% minoxidil ethanolic solution) by an enlargement of follicular size and prolongation of the anagen phase. It holds the promise of potent herbal alternative for minoxidil. Excellent results of hair growth were seen in formulation prepared by cloth pouch decoction method of oils preparation technique.
\end{abstract}

Keywords: Hair formulation, Herbal oil, Euphorbiaceae, Leguminosae, Scrophulariaceae, Rutaceae

\section{Introduction}

Hair suffers aggression; there can be some aliments to normal health of hair and cause trouble. The main problems associated with hair such as pigmentation problems (Fading), dandruff and falling of hair (Shedding) ${ }^{1}$. Synthetic drug, minoxidil is a potent vasodilator appears safe for long-term treatment. After five years use of 2 and 3\% topical minoxidil, 
the improvement has been shown to peak at one year with a slow decline in regrowth over subsequent years ${ }^{2}$. Long-term treatment with local side effects may be a problem with continuing used of minoxidil lotion ${ }^{3,4}$. On the basis of market survey carried out on crude drugs used presently for herbal hair oils gives us clue for selection of drugs for hair oil. Hence the present study was aimed to evaluate the hair growth activity of herbal formulations, which includes oil extract of all mentioned drugs in various concentrations. The Plant Emblica officinalis belongs to family Euphorbiaceae. Amla is rich source of vitamin C and contains appreciable amount of pectin rich in mineral matters like phosphorous, iron, and calcium ${ }^{5}$. Bacopa monnieri belongs to the family Scrophulariaceae, is known for its action on brains so that it is called as nervine tonic. It has been reported that bacosides A \& B enhance protein kinase activity and new protein synthesis in cells. So that it is also used for treatment of dementia ${ }^{6}$. Trigonella foenum-graecum belongs to family Leguminosae used as high protein fodder and for its cleansing and softening activity. It promotes scalp health and prevents hair falling ${ }^{7}$. Leaves of Murraya koenigii belongs to family Rutaceaceae is used for its antiseptic properties ${ }^{8}$. Cocus nucifera from the family Palmae is said to promote the growth of hair.

\section{Experimental}

\section{Collection and identification of plant}

The fruits of Embelica officinalis; leaves of Bacopa monnieri; leaves of Murraya koeniigi; seeds of Trigonella foenumgraecum were purchased from local market and identified by comparing with standard herbarium specimens available in AICRP on Medicinal \& Aromatic plants, J.N. Krishi Vishwa Vidyalaya, College of Agriculture, Indore. The various parts of plant drugs are crushed in mixer and passed through the sieve number 80 . The various powder drugs were subjected to pharmacognostic studies for confirmation.

\section{Preparation of hair formulation}

The hair formulations of 1,2 and 3\% of Embllica officinalis, Bacopa monnieri, Murraya koeniigi, Trigonella foenumgraecum of each drugs were separately prepared by cloth pouch method and similarly the 4, 5, 6, 7, 8, 9 and 10\% formulation of each drugs were prepared. The method used for carrying out these formulations was holding the individual drug in cloth pouch and boiling continuously with stirring arrangement.

\section{Hair growth initiation test}

Quantitative modified model for the study of hair growth initiation was followed. The rabbits were divided into four groups of one rabbit named as group A, B, C and D respectively $2 \mathrm{~cm}^{2}$ area of surface of each rabbits shaved area to remove all the hairs. Approximately 11 patches on each rabbit with a distance of $5 \mathrm{~cm}$ were developed. Group A was treated with amla oil with respective concentration of $1 \mathrm{~mL}$ each of $1-10 \%$ on each patch $\left(A_{1}-A_{10}\right)$ keeping first patch as control. Group B was treated with brahmi oil with respective concentration of $1 \mathrm{~mL}$ each of 1 $10 \%$ on each patch $\left(\mathrm{B}_{1}-\mathrm{B}_{10}\right)$, keeping first patch as control. Group $\mathrm{C}$ was treated with methi oil with respective concentration of $1 \mathrm{~mL}$ each of $1-10 \%$ on each patch $\left(\mathrm{F}_{1}-\mathrm{F}_{10}\right)$, keeping first patch as control. Group D was treated with meetha neem oil with respective concentration of $1 \mathrm{~mL}$ each of $1-10 \%$ on each patch keeping first patch as control. This treatment was continued for 15 days during the course the hair growth initiation pattern was observed and reported.

\section{Preparation of combined drug herbal hair formulation of different concentration.}

After confirming the preliminary growth initiation with individual drug oil the all drugs are selected and mixed in three concentration as $2.5,5, \& 7.5 \%$ for maximum ${ }^{9}$ activity (Table 1 ). 
Table 1. Selection of Concentration of Oil for Hair Growth Activity.

\begin{tabular}{ccccc}
\hline \multicolumn{5}{c}{ Amount of drugs/100mL of oil, g } \\
\hline$\%$ & Amla & Brahmi & Methi & Meetha Neem \\
\hline 2.5 (OD1) & 2.5 & 2.5 & 2.5 & 2.5 \\
5.0 (OD2) & 5.0 & 5.0 & 5.0 & 5.0 \\
7.5 (OD3) & 7.5 & 7.5 & 7.5 & 5.0 \\
\hline
\end{tabular}

\section{Primary skin irritation test}

The institute has been cleared for the said biological evaluation by Animal Ethics Committee (Letter No.465/01/AB/CPCSEA). Three healthy male rats, weighed 200-250g were selected for the study. Each rat was caged individually food and water given during the test period $24 \mathrm{hrs}$ prior to the test. The hair from the back of each rat of $1 \mathrm{~cm}^{2}$ was shaved on the side of the spine to expose sufficiently large test areas, which could accommodate three test sites were cleaned with surgical sprit. $1 \mathrm{~mL}$ quantity $(5 \% \mathrm{w} / \mathrm{w})$ of the formulations OD1, OD2 and OD3 were applied over the respective test sites of one side of the spine. The test sites were observed for erythema and edema for $48 \mathrm{~h}$ after application ${ }^{12}$.

\section{Chemical evaluation}

The prepared formulations were evaluated using standard methods of general characterization, physical and chemical evaluation including specific gravity, $\mathrm{pH}$, refractive index, acid value and saponification value.

Male wistar albino rats, 200-250g, from Veterinary College, Mhow were used for hair growth studies. They were placed in cages and kept in $\left(23{ }^{\circ} \mathrm{C} \pm 10,60 \% \pm 10 \mathrm{RH}\right)$ standard environmental conditions, fed with (Hindustan Liver) standard diet and allowed free access to drinking water for two days. The prepared formulations were assessed for the standard test.

\section{Hair growth activity test}

Quantitative model developed by $\mathrm{Uno}^{12}$ for the study of hair growth was followed with slight modification. The rats were divided into 8 groups of 5 rats each $2 \mathrm{~cm}^{2}$ area of dorsal portion of all the rats shaved area to remove all the hair. Group 1 was kept as control, where there was no drug treatment. Group 2 was treated as standard, where $1 \mathrm{~mL}$ of (2\% Minoxidil ethanolic solution) was applied over the shaved area, once a day. The animals of remaining group were given application of $1 \mathrm{~g}(5 \% \mathrm{w} / \mathrm{w})$ of formulation OD1, OD2 and OD3 respectively and $1 \mathrm{~mL}(5 \% \mathrm{w} / \mathrm{v})$ of OD1, OD2 and OD3 respectively, once a day. This treatment was continued for 30 days. During the course the hair growth pattern was observed qualitatively and recorded ${ }^{13,14}$.

\section{Results and Discussion}

The results of general characteristics, physical and chemical evaluation are summarized in Table $2 \& 3$. Primary skin irritation test was conducted to evaluate the irritation by the prepared formulations on intact skin of rabbits. All of the prepared formulations were not showed any erythema and/or edema; this indicates that the prepared formulations were nonirritant on skin of rabbits. In hair growth initiation test the activity of various concentration of hair oil were recorded in terms of qualitative changes various biological parameters formed during treatment of oil with respect to normal untreated animals. This parameter is recorded for finding minimum effective concentration of drug. A7 \& A8 (7\% \& 8\% of Amla Powder) showed a significant increase of hair follicles with in $15 \mathrm{~d}$. Both of this concentration showed 
growth initiation for hair follicle within 9 and 8 . Similarly B7 \& B8 $(7 \%$ \& 8\% of Brahmi powder) showed a significant increase in number of hair follicles up to 12 with in $6 \mathrm{~d}$. Along with this $\mathrm{f} 7$ and $\mathrm{f} 8$ (7\% and $8 \%$ concentration of fenugreek) showed a significant increase in hair follicle 8 and 9 respectively in $9 \mathrm{~d}$. The oil containing M7 and M8 (7\% and 8\% concentration of Meetha neem) showed early initiation of hair growth follicle in $6 \mathrm{~d}$ with 11 numbers.

Table 2. Evaluation of general characteristics.

\begin{tabular}{cccc}
\hline Concentration in & $2.5 \%$ & $5 \%$ & $7.5 \%$ \\
\hline Colour & Green & Green & Greenish black \\
Odour & - & - & Characteristic \\
\hline
\end{tabular}

Table 3. Evaluation of physical parameters.

\begin{tabular}{cccc}
\hline \multirow{2}{*}{ Parameters } & \multicolumn{3}{c}{ Concentration } \\
\cline { 2 - 4 } & $2.5 \%$ & $5 \%$ & $7.5 \%$ \\
\hline Specific Gravity & 0.928 & 0.9384 & 0.9432 \\
$\mathrm{pH}$ & 9.1 & 8.4 & 7.5 \\
Refractive index & 1.505 & 1.472 & 1.435 \\
Acid Value & 2.49 & 2.18 & 1.558 \\
Saponification value & 256 & 256.9 & 257 \\
\hline
\end{tabular}

From the significant quantitative changes shown by various hair oil were further subjected for hair growth activity and results are shown in Table 4 and 5 respectively.

Table 4. Qualitative observation of hair growth.

\begin{tabular}{cccc}
\hline Formulation & $\begin{array}{c}\text { Number } \\
\text { of Rats }\end{array}$ & $\begin{array}{c}\text { Time taken to } \\
\text { initiate the } \\
\text { growth in d }\end{array}$ & $\begin{array}{c}\text { Time taken for complete } \\
\text { growth in d }\end{array}$ \\
\hline Control (untreated) & 5 & 8 & 24 \\
Minoxidil (standard) & 5 & 7 & 19 \\
OD1 & 5 & 10 & 25 \\
OD2 & 5 & 9 & 23 \\
OD3 & 5 & 8 & 18 \\
\hline
\end{tabular}

Table 5. The rate of hair growth.

\begin{tabular}{|c|c|c|c|c|c|c|c|c|}
\hline \multirow{3}{*}{$\begin{array}{c}\text { Formulation } \\
\%\end{array}$} & \multicolumn{4}{|c|}{ Mean length, $\mathrm{mm}+50$} & \multicolumn{4}{|c|}{ Population, \% } \\
\hline & \multicolumn{2}{|c|}{ Anagen } & \multirow{2}{*}{ Catagen } & \multirow{2}{*}{ Telogen } & \multicolumn{2}{|c|}{ Anagen } & \multirow{2}{*}{ Catagen } & \multirow{2}{*}{ Telogen } \\
\hline & $\mathrm{A} 3$ & A5 & & & A3 & A5 & & \\
\hline Control & - & $0.62+0.13$ & $0.11+0.02$ & $0.22+0.06$ & - & 47 & 4 & 49 \\
\hline Standard & $0.46 \pm 0.04$ & $0.73 \pm 0.11$ & 0.1 & $0.23 \pm 0.06$ & 18 & 49 & 1 & 32 \\
\hline 2.5 & $0.42 \pm 0.04$ & $0.65 \pm 0.11$ & - & $0.20 \pm 0.04$ & 22 & 46 & - & 19 \\
\hline 5.0 & $0.40 \pm 0.05$ & $0.70 \pm 0.11$ & 0.1 & $0.22 \pm 0.05$ & 21 & 59 & 2 & 29 \\
\hline 7.5 & $0.45 \pm 0.06$ & $0.73 \pm 0.14$ & - & $0.25 \pm 0.05$ & 23 & 62 & 1 & 17 \\
\hline
\end{tabular}

The time taken for complete hair growth was $18 \mathrm{~d}$ in OD3 and $19 \mathrm{~d}$ in minoxidil. Table 4 shows the hair growth response within 21d. Thus on comparison OD3 and minoxidil it has been observed that patch with $7.5 \%$ hair oil formulation application shows better growth that the patch with minoxidil. On comparison with OD3 and minoxidil the complete growth of standard and OD2 was found to be $24 \mathrm{~d}$ and $23 \mathrm{~d}$ respectively. 
The quantitative study revealed that formulation OD3 considerable increase in number of hair follicle in anagen phase of hair growth cycle, when compare to standard and control. In standard group percentage of population of anagen follicle was $67 \%$, where as in formulation OD3 it was $83 \%$ and OD2 $81 \%$. Similarly the formulation OD1 and OD2 were shown time of initiation of hair growth late when compared with standard and control. It also observed that the time taken for complete hair growth the late initiation and completion of hair growth was $25 \mathrm{~d}$ in OD1 and 23d in OD2 indicating late initiation and completion of hair growth. The result shows that formulation OD3 have contributed in most significant hair growth activity. Similarly, the way of method of preparation of OD3 $(7.5 \%$ concentration of all drugs) boiling in pouch method showed maximum extraction of active principles responsible for hair growth. The hair growth studies finally prove that formulation OD3 have significant increase in hair growth activity when compared to the standard. It holds the promise of potent herbal alternative for minoxidil. Also suggest excellent results of hair growth in formula prepared by cloth pouch boiling method.

\section{References}

1. Butler H, Poucher's Perfumes, Cosmetics and Soaps, $9^{\text {th }}$ Ed.,Vol-III, Chapman And Hall, London, 1993, 130.

2. Olsen E A, Weinerr M S and Amara I A, J. Am. Acad. Dermatol. 1990, 22, 643.

3. Wilson C, Walkden V and Powell S, Brit. J. Acad. Dermatol. 1991 24, 661.

4. Bhalerao S S and Solanki N H, Indian Drugs, 2002, 39, 567.

5. Kokate C K, Purohit A P and Gokhale S B, In; Pharmacogonosy, $19^{\text {th }}$ Ed., Nirali Prakashan, Pune, 2002, 224.

6. Shah C S, Qudry J S, A Text book of Pharmacognosy, $11^{\text {th }}$ Ed., B.S. Shah Prakashan, Ahmedabad, 1996, 119.

7. Evans W C, Trease and Evans. Pharmacognosy, $15^{\text {th }}$ Ed., W.B. Saunders Harcourt Publishers Ltd., 2002, 292.

8. Kritikar K R, Basu B D, Indian Medicinal Plants, $2^{\text {nd }}$ Ed., Lalit Mohan Basu, Allahabad, 1999, 472.

9. The Aurvedic Formulary of India, Government of India, Ministry of Health and Family Planning, Department of Health, Delhi, $1^{\text {st }}$, Ed., 1978, Part I, 99.

10. Pharmacopoeia of India, Govt. of India, Ministry of Health, The Manager of Publication, New Delhi, 1996, Vol-II, 1-73, A-54.

11. Chauduri S K, Concise Medical Physiology, $2^{\text {nd }}$ Ed., New Central Book Agency (P) Limited, Calcutta, 1996, 503.

12. Uno H, Stenn K S, Massenger A G and Baden H P, Molecular and Structural Biology of Hair, Quantitative models for the study of hair growth in vivo. N.Y. Acad. Sci., 1991, 642.

13. Mithal B M, Shah R N, A Hand Book of Cosmetics, $1^{\text {st }}$ Ed., Vallabh Prakashan, Delhi, 2000.

14. Tortora G J, Grabowski S R, Principles of Anatomy and Physiology, $8^{\text {th }}$ Ed., Harpercollins Publishers, Menlopark, California, 1996, 129. 


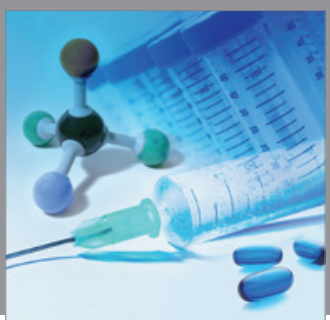

International Journal of

Medicinal Chemistry

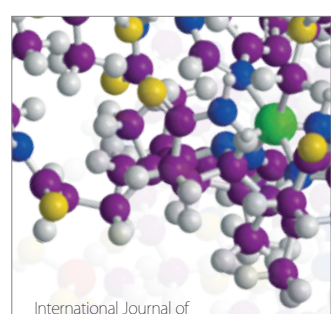

Carbohydrate Chemistry

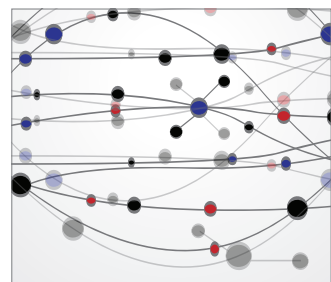

The Scientific World Journal
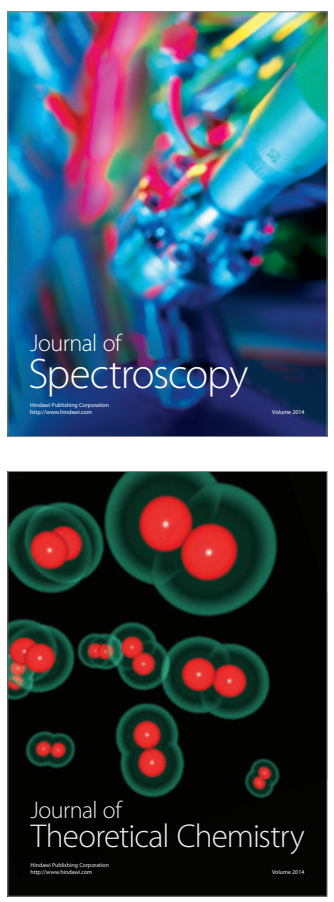
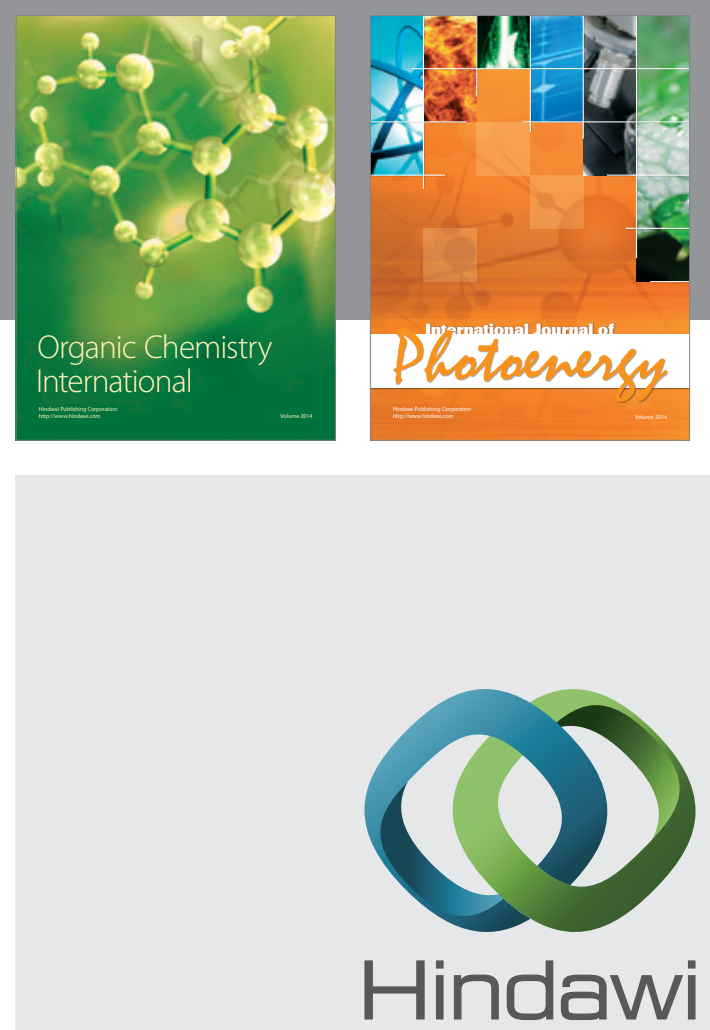

Submit your manuscripts at

http://www.hindawi.com
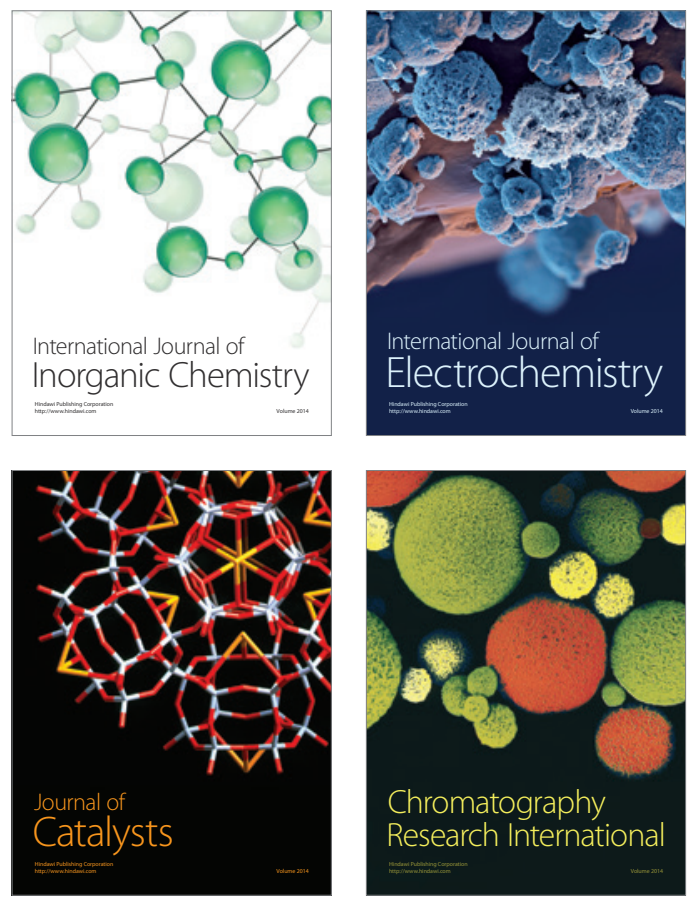
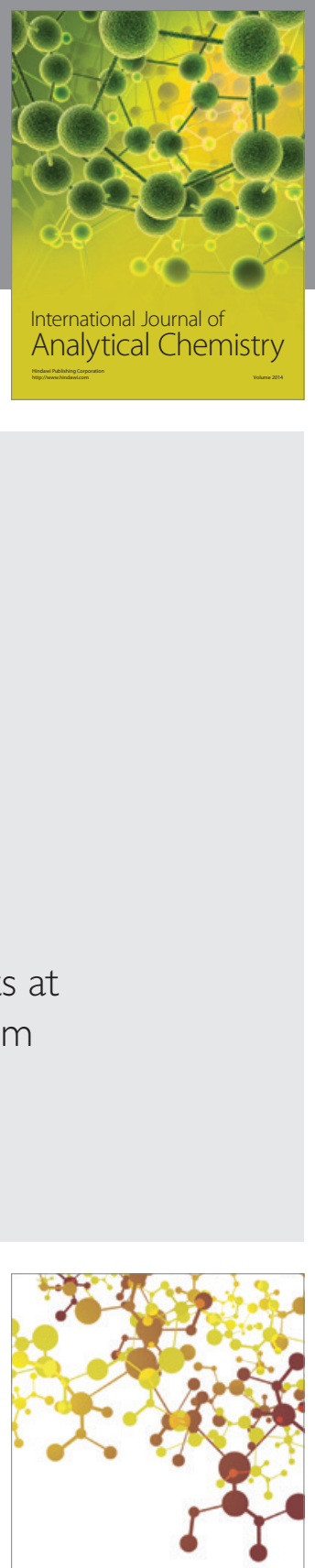

Journal of

Applied Chemistry
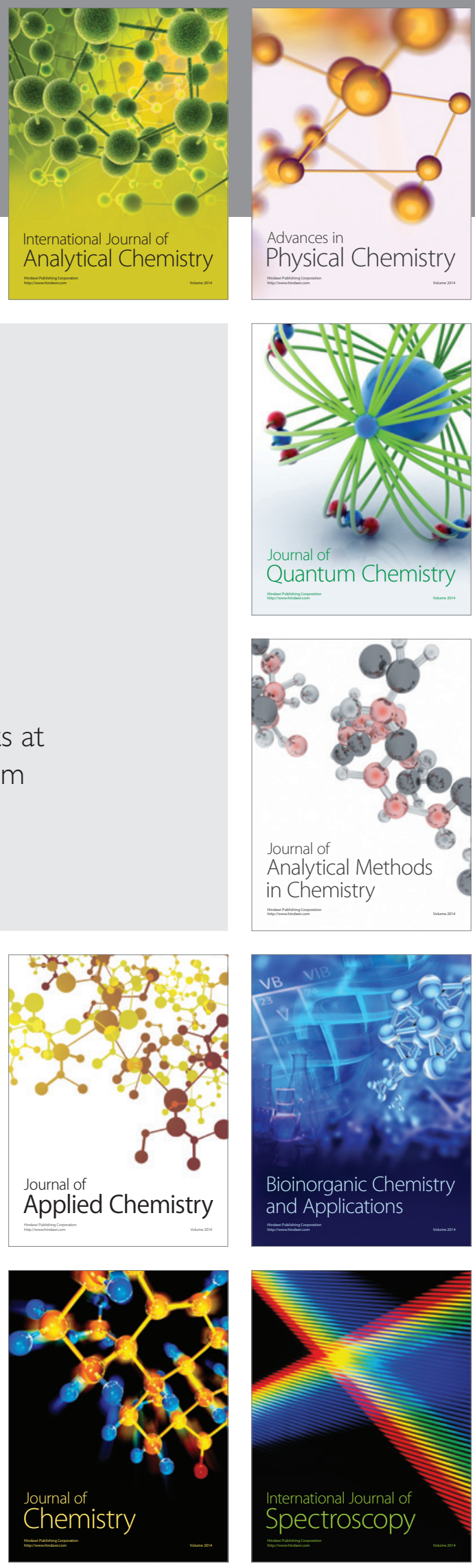